Thus, taking into account the fact that interdisciplinary integration is a necessary process of modern education, we came to the conclusion that the active participation of students of a technical university in a scientific conference in a foreign language is an effective means of interdisciplinary integration in the educational sphere for continuous and holistic self-development of a future specialist in the technical field. In the training of future specialists in the technical field for a teacher, it is important to develop the ability of students to apply knowledge from different fields in a comprehensive manner, as well as the ability to transfer basic ideas from one field of science to another, which is also facilitated by students' research work and their active participation in scientific conferences [8].

$$
* * *
$$

1. Afanasyeva O. Yu. Communicative education of students of pedagogical universities based on the idea of interdisciplinarity // Pedagogical education and science. 2006. No. 2. p. 24-28.

2. Vishnyakova E. G. Interdisciplinary network educational and methodological complex as a means of increasing the effectiveness of training at a university: abstract diss. ... to ped. Volgograd, 2007. p.23.

3. Vlasova IV. The use of interdisciplinary integration in the system of formation of general cultural competencies in students of chemical specialties of a technical university // Modern problems of social sciences and humanities: Sat. reports of the 1st All-Russian scientific and practical correspondence conference. Kazan: Fatherland, 2015.p. 60-63.

4. Krivorotova T. A. Integration as a factor in the development of a new quality of education // Economics. Right. Education: a regional aspect. Nizhny Novgorod: Publishing House Gladkova O.V., 2010.p. 233238.

5. Krivorotova T. A. The socio-cultural nature of educational processes through the prism of modernization of social and humanitarian knowledge // Education. Economy. Law: the transformation process and performance criteria: materials of the VII international scientific conference. M .: MIEMP, 2011.p. 481482.

6. Skorikova T. P. Fundamentals of the culture of scientific speech in the system of university training of a modern specialist // Speech communication: specialized bulletin. 2002. Issue. 4 (12). p. 184-187.

7. Chernenko N. M. The concept of scientific communication: the generation of information texts // Classical linguistic education in the modern multicultural space: materials of an international scientific conference. Pyatigorsk: Pyatigorsk Linguistic University, 2004.p. 108 - 113.

8. Shestakova L. A. Formation of a fund of assessment tools in the process of interdisciplinary integration in a modern university // Bulletin of the Nizhny Novgorod State Technical University. R. E. Alekseeva. Series "Management in social systems. Communicative technologies. " 2012. No. 4. p. 102-109.

\title{
Grishchenko E.G. \\ Modern professional standards: impulse to self-development or "Vice" for the teacher?
} Belgorod National Research University (Russia, Belgorod)

doi: $10.18411 / \mathrm{lj}-02-2020-166$

idsp: ljournal-02-2020-166

\section{Аннотация}

В статье рассматриваются актуальные вопросы, касающиеся современных профессиональных стандартов в области образования. По мнению автора, сегодня на первый план выходят не личностные качества работников образования, а их умения в области применения современных технологий, работы с разными группами детей, знания иностранных языков, что зачастую не совсем оправдано. Автор, поднимая проблему завышенных требований, которые современные профессиональные стандарты предъявляют к учителям, говорит о том, что данные запросы государства ставят перед педагогами порой невыполнимые задачи, тем самым усложняя организацию образовательного процесса.

Ключевые слова: педагог, учитель, компетентность, образовательные стандарты, профессиональные требования 


\section{Abstract}

The article deals with topical issues related to modern professional standards in the field of education. According to the author, today it is not the personal qualities of education workers that come to the fore, but their skills in the application of modern technologies, working with different groups of children, and knowledge of foreign languages, which is often not entirely justified. The author, raising the problem of overstated requirements that modern professional standards impose on teachers, says that these requests of the state sometimes put impossible tasks before teachers, thereby complicating the organization of the educational process.

Keywords: educator, teacher, competence, educational standards, professional requirements.

Teacher. In all times, the attendant of pedagogy were treated with respect, revered and appreciated. The profession of a teacher is still one of the most respected and revered in society. Moreover, it is safe to say that today it is in demand, perhaps, as never before. It is worth noting that if earlier teachers were associated exclusively with the school, in our age the situation has changed radically. More and more teachers of different profiles are coming out of the walls of educational institutions, and they are necessary in various spheres of our life, this is one of the features of the teacher's profession.

But what does it ultimately mean to be a good pedagogue, teacher, educator, instructor in the twenty-first century? What are the requirements for modern keepers of knowledge and experience, and how do these requirements affect the activities of the teacher: open new horizons for creativity and self-development or "quadrated", driven into the "Vice" and a heavy burden falls on the shoulders of education workers?

Before giving a characteristic of the modern education system, it is necessary to determine the place of the teacher in it, what role in the pedagogical process is assigned to the teacher today: the main or episodic? To answer these questions, let's remember how teachers were treated at least a century or half a century ago?

Undoubtedly, the teacher was assigned one of the first places, because it depended on him how high the quality of the transmitted knowledge, skills and abilities would be. And the more experienced and stronger the teacher, the better in all respects were his students. The attitude to the teacher, the educator was reverent. The students respected the teacher, and the teachers were proud of their profession and demanded complete dedication from themselves. Let us recall the words of the outstanding teacher of all times and peoples K. D. Ushinsky, who wrote that "the educator is a living link between the past and the future".

It should be noted that in the last century, too, cared about the quality of teaching, distinguished types and functions of pedagogical activity (I. F. Kharlamov, N. V. Kuzmina, etc.). The traditional ones were mainly: teaching, educating, social and pedagogical. Having studied the traditions of the Russian intelligentsia, we see that the teacher has never been limited in his activities only by the official framework. He conducted both educational activities, and carried out interaction with parents, etc. What do we see now?

The functions of pedagogical activity are constantly updated, and teachers already perceive methodological, research, innovative, self-educational and other functions quite normally. Today the full commitment required by teachers of educational laws, normativelegal acts and various standards that make greater demands on the teacher's personality, and these requirements sometimes seem impossible for experienced teachers and graduates of teacher training colleges, often simply find ourselves in desperate situations of the isolation of theory from the realities of practice.

Nevertheless, the state perceives the need to introduce a professional standard as a system mechanism for evaluating practicing teachers during certification tests, a resource for professional career growth. As it was stated by D. V. Livanov in 2015, every teacher should 
perceive the professional standard as a coordinate system that will help each teacher to build their individual trajectory of professional and personal growth.

Speaking about the profession of teacher today and perceiving it in the modern context of the national system of teacher growth and success, we can confidently say that every educator, teacher, instructor should be prepared for the fact that in modern socio-economic conditions it will require special knowledge and skills. This is due to the high role of the teacher in the life of their students. After all, it is the teacher who has the opportunity to form a personality, a real person. Due to the fact that today, in a democratic state, the man as a person who requires attention and respect comes to the fore for teachers to recreate more rigid ideals.

Every year the characteristics of a teacher worthy of being called competent change. New professional standards appear, which, as it seems to us, further and further distance teachers from their cherished goal-to meet modern requirements, to do what they love, teaching and educating students of various categories. New professional standards dictate more and more responsibilities, in which less and less space is given to rights.

"The document meets all the requirements that the society of the teacher's profession today imposes," Dmitry Livanov, the current Minister of education in those times, described the new professional standard of a teacher, which came into force in 2015 on behalf of President Vladimir Putin.

If we analyze these requirements, we can assume that about 100 people across the country fully meet them. Since 2015, the teacher must not only organize classes, conduct educational work, but also know the features of interaction with all categories of children: the backward in development, gifted, with limited health opportunities, the disabled, those for whom the Russian language is not their native language.

Also, according to the new requirements, the teacher must be a good psychologist, understand the child's development crises, its individual characteristics, build individual development trajectories in accordance with them, and know a foreign language. In the section "Necessary skills" it is said that the teacher should be able to apply all these skills regardless of the age of children in all types of classes.

Commenting on these criteria, Vsevolod Lukhovitsky noted that these are the requirements for an ideal teacher, who can safely be awarded the title of honored teacher of Russia.

Dmitry Livanov, describing the new standard, assured that it is fully ready for implementation, but are the teachers ready for it themselves? And is the state itself ready for this? In our opinion, in order for all Russian teachers to meet the requirements of professional standards, it is necessary to completely change the training system. During the period that is allocated for professional development, it is impossible to teach the subtleties of introducing pedagogical innovations, defectology, psychology, speech therapy, etc. It should be recognized that in modern conditions, the above requirements are practically impossible, if only because at present there are no conditions for their implementation.

The great difficulties that arise before the teacher make him helpless. Children with disabilities require special treatment from not only teachers, but also all people in the institution. Today the teacher, as a rule, is not ready to work in such conditions, he is not taught - neither in pedagogical higher education institution, nor in Institute of advanced training. But, despite this, we continue to actively develop the topic of joint education of children of different health groups, forgetting that inclusive education is not just a joint training of children with disabilities and children with the norm, it is a complex process of restructuring the entire pedagogical system, which is not ready, first of all, teachers.

In the preamble to the professional standard of the teacher it is said that it is impossible to demand from the teacher what no one has ever taught him, but these words have long become irrelevant. In this regard, it would be most appropriate if the discussion and implementation of new standards regulating the work of teachers and new requirements for 
them should be followed by the development of a standard for training teachers: both in higher education and in institutions of teacher training [5].

This raises a question, which, perhaps, should be seriously considered: is it correct that the qualification of a teacher is measured by his various skills in the field of modern technology, knowledge of foreign languages and talents in working with gifted children? Perhaps, after all, the main indicator that a person really has every right to proudly wear the title of teacher is the respectful, reverent attitude of his students towards him?

It is important to remember that perhaps the most important standards that define the requirements for the teacher, the criteria that should be based on every true teacher were laid down many decades ago. Even Konstantin Dmitrievich Ushinsky-the founder of Russian scientific pedagogy in his works wrote that only the individual is subject to act on the development and definition of personality, that only the character can form a character. It is the character, and not written on paper laws and regulations, which tomorrow may lose their force.

So what is it that we must rely up on education of the new generation? What to strive for? To the standards of quality of training and education checked for years or to new ideals of skill of teaching? We are -future and current teachers -we can only continue to speculate on this topic and anxiously or hopefully wait for new professional standards.

$$
* * *
$$

1. Sidorov S. V. / / Site of the teacher-researcher. - URL: http://si-sv.com/board/13-1-0-36 [accessed 10.03.2017].

2. Livanov D. V. Introductory speech to the thematic issue "Professional standard of the teacher" / D. V. Livanov / / Psychological science and education. - 2016. - Volume 21. - No. 2. - P. 5-6.

3. Professional standard of the teacher. "Information and methodological center" of Krasnoselsky district. Results of the survey. - URL: http: / / profstandart. blogs. imc.edu. ru / questionnaire/survey results/ [accessed 03/04/2017].

4. The Order of the Ministry of labor of Russia from 18.10.2013 No. 544n (with ed. from 25.12.2014) "About the approval of the professional standard" Teacher (pedagogical activity in the field of preschool, primary General, basic General, secondary General education) (educator, teacher)". - P. 44.

5. Chernykh A. Teachers put forward increased requirements / A. Chernykh / / Kommersant. - 2013. December 7.

6. Uspensky V. B. Introduction to psychological and pedagogical activity: studies. manual / V. B. Uspensky, A. p. Chernyavskaya. - Moscow: VLADOS-PRESS, 2003. - $176 \mathrm{~s}$.

\section{Yashina A., Mefodeva M., Markelova I. \\ Directions and mechanisms of optimization and development of rural ungraded schools in Russia}

Kazan (Volga region) Federal University

(Russia, Kazan)

doi: $10.18411 / \mathrm{j}-02-2020-167$

idsp: ljournal-02-2020-167

\section{Abstract}

The issue of rural ungraded schools is rather relevant nowadays as they have a set of specific problems that are peculiar only for them. These problems are the reason for closing rural ungraded schools down. Main directions and mechanisms of optimization and development of rural ungraded schools are considered.

Key words: rural ungraded schools, modernization of education system, implementation of learning services, remoteness, rural area, rural schoolchildren.

Social, economic and political processes in modern society presume the modernization of the entire education system, which is particularly relevant for rural schools. Rural schools located in remote rural settlements are characterized by a small number of both schoolchildren 